\title{
Amine metabolites in ventricular cerebrospinal fluid in coma
}

\author{
CELIA M. YATES, S. A. TSEMENTZIS, AND HELEN WILSON \\ From the MRC Brain Metabolism Unit, Department of Pharmacology, and the Department of \\ Surgical Neurology, University of Edinburgh, Edinburgh
}

SUMMARY The concentrations of homovanillic acid (HVA), 3-methoxy, 4-hydroxyphenylglycol (MHPG), and 5-hydroxyindolylacetic acid (5-HIAA) were measured in samples of ventricular cerebrospinal fluid (CSF) taken from 15 patients who were comatose as a result of an acute head injury, a tumour, or a cerebrovascular accident. The metabolite levels were not related to the ventricular fluid pressure. In the eight patients who recovered and from whom serial samples of CSF were obtained, the metabolite levels did not change, except for two patients in whom HVA increased as coma progressed. The concentration of MHPG, but not of HVA or 5-HIAA, was greater $(P<0.02)$ in the five patients who died without regaining consciousness than in the 10 patients who recovered.

Patients with severe, acute head injury frequently show clinical signs of brainstem damage. In experimental animals (Dahlström and Fuxe, 1964) the cell bodies of ascending dopaminergic (DA), noradrenergic (NA), and 5-hydroxytryptaminergic (5-HT) neurones lie within the brainstem. Lesions of certain of the dopaminergic and noradrenergic cell bodies reduce wakefulness, while lesions of the 5-hydroxytryptaminergic cell bodies tend to increase wakefulness (Jouvet, 1972). The loss of consciousness which accompanies brainstem injury in man might, therefore, be related to damage to one or all of these aminergic systems. We have investigated this possibility by measuring the concentrations of the metabolites of DA, NA, and 5-HT-namely, homovanillic acid (HVA), 3methoxy, 4-hydroxyphenylglycol (MHPG), and 5-hydroxyindolylacetic acid (5-HIAA)-in serial samples of ventricular cerebrospinal fluid (CSF) taken from patients with coma after an acute head injury. Patients with brain tumours or cerebrovascular accidents who had coma of a progressive nature which was not accompanied by signs of brainstem injury served as control subjects.

\footnotetext{
Address for reprint requests: Celia M. Yates, MRC Brain Metabolism Unit, Department of Parmacology, University of Edinburgh, 1 George Square, Edinburgh EH8 9JZ.

Accepted 20 April 1979
}

\section{Patients and methods}

Two groups of comatose patients who were acute admissions to the Departments of Surgical Neurology at the Royal Infirmary and Western General Hospital, Edinburgh, were studied. Group 1 comprised nine patients (eight males and one female) with coma caused by acute head injury, usually traffic accidents. Group 2 was composed of six patients (four males and two females) with coma associated with a tumour or a cerebrovascular accident.

A rigid polyethylene cannula was implanted into the right lateral ventricle and connected via a three-way tap to an extracranially sited pressure transducer and a drainage tube. The former was used to monitor continuously the ventricular fluid pressure (VFP) (Tsementzis, 1978) and the latter was positioned to allow withdrawal of CSF in cases of increased VFP. Patients were selected for this study by the absence of any CSF drainage on opening the drainage tap. The catheter was implanted in group 1 within 12 hours of the accident, and in group 2 once the coma had become continuous. With the exception of one tumour patient, all patients received various combinations of the following drugs: penicillin, sulphadimidine, dexamethasone, mannitol, diazepam, nitrazepam, gallamine, curare, phenytoin, phenoperidine, and 
papaveretum, and two patients were given metoclopramide and chlorpromazine respectively. Some patients were ventilated.

Samples of ventricular CSF were withdrawn at various times throughout the period, not longer than seven days, that the cannula was left in situ. The first sample was taken within 12 hours of insertion of the cannula. Subsequent samples, maximum number seven, were removed at intervals of not less than four hours. Cerebrospinal fluid $(0.5-3.0 \mathrm{ml})$ was withdrawn using a syringe inserted into the drainage tube outlet. The CSF was immediately centrifuged and the clear supernatant fluid stored at $-20^{\circ} \mathrm{C}$ until analysed. Coloured samples were discarded.

Homovanillic acid and 5-HIAA were measured fluorimetrically in $0.4-1.0 \mathrm{ml}$ ventricular CSF (Davidson et al., 1977). Total and free MHPG were assayed in two separate portions of ventricular CSF, of $0.5-1.0 \mathrm{ml}$. Total MHPG was assayed by gas-liquid chromatography after incubation with the sulphatase preparation "Helicase" to hydrolyse MHPG sulphate (Davidson et al., 1977). Free MHPG was assayed in exactly the same way as total MHPG except that Helicase was not added. Protein was measured by the method of Lowry et al. (1951) .
All statistical comparisons were made using Student's $t$ test and a value of $P \leqslant 0.05$ was taken to indicate a significant difference.

\section{Results}

The results from the head injury patients are given in Table 1 (cases 1-9) and from the tumour and cerebrovascular patients in Table 2 (cases 1015). The level of CSF protein was high in cases $1,2,3,5,7,8,13$, and 15 . Cases $1,3,7$, and 15 had intracerebral haematomas. Case 13 had hydrocephalus, and case 5 subsequently developed hydrocephalus. Free MHPG in eight patients with acute or chronic injuries ranged from $42 \%$ to $100 \%$ with a mean ( \pm SD) of $75 \pm 24 \%$. There was no significant difference between the mean metabolite concentrations in samples taken on day 0 , in the two patient groups. There was no significant correlation, in either patient group, between the metabolite concentrations in samples taken on day 0 and age or VFP. Throughout the sampling period the VFP remained fairly constant.

Repeat samples of ventricular CSF were obtained from eight of the nine head injury patients (Table 1) and from two of the six patients with

Table 1 Concentrations of HVA, 5-HIAA, and MHPG $(\mathrm{ng} / \mathrm{ml})$ in serial samples of ventricular CSF from patients who were comatose after head injury

\begin{tabular}{|c|c|c|c|c|c|c|c|c|c|}
\hline & Case & $\begin{array}{l}\text { Age } \\
(y r)\end{array}$ & $\begin{array}{l}\text { Days after } \\
\text { insertion of } \\
\text { cannula }\end{array}$ & $\begin{array}{l}V F P^{+} \\
(m m H g)\end{array}$ & $H V A$ & $5-H I A A$ & $\begin{array}{l}\text { MHPG } \\
\text { Total }\end{array}$ & $\begin{array}{l}\text { MHPG } \\
\text { Free }\end{array}$ & $\begin{array}{l}\text { Protein } \\
(\mathrm{mg} / \mathrm{ml})\end{array}$ \\
\hline Recovered & $\begin{array}{l}3 \\
4\end{array}$ & $\begin{array}{l}17 \\
45 \\
18\end{array}$ & $\begin{array}{l}0 \\
3 \\
0 \\
2 \\
3 \\
0 \\
8 \\
0 \\
2 \\
3 \\
0 \\
0 \\
3\end{array}$ & $\begin{array}{l}8-9 \\
12-15 \\
12-15 \\
15 \\
15 \\
30-35\end{array}$ & $\begin{array}{r}207 \\
186 \\
330 \\
707 \\
1324 \\
406 \\
392 \\
446 \\
456 \\
332 \\
130 \\
157 \\
174\end{array}$ & $\begin{array}{r}91 \\
70 \\
95 \\
47 \\
71 \\
108 \\
-\overline{141} \\
164 \\
100 \\
77 \\
57\end{array}$ & $\begin{array}{l}13 \\
17 \\
13 \\
14 \\
48 \\
14 \\
17 \\
22 \\
22 \\
17 \\
14 \\
-\end{array}$ & $\begin{array}{l}-\overline{1} \\
\overline{12} \\
\overline{17} \\
6 \\
12 \\
13 \\
\frac{13}{-} \\
-\end{array}$ & $\begin{array}{l}1.29 \\
0.73 \\
0.54 \\
0.41 \\
0.75 \\
0.55 \\
0.24 \\
0.42 \\
0.41 \\
0.90 \\
0.26 \\
0.20\end{array}$ \\
\hline Died & $\begin{array}{l}7 \\
8\end{array}$ & $\begin{array}{ll}33 & \\
27 & \\
27 & \begin{array}{l}\text { Intermittent } \\
\text { drainage }\end{array}\end{array}$ & $\begin{array}{l}0 \\
4 \\
0 \\
3 \\
5 \\
0 \\
1 \\
1.5 \\
2 \\
3 \\
5 \\
6\end{array}$ & $\begin{array}{l}<20 \\
30-45 \\
50-60\end{array}$ & $\begin{array}{r}255 \\
440^{*} \\
174 \\
4 \quad 40 \\
81 \\
225 \\
359 \\
241 \\
302 \\
286 \\
260 \\
171\end{array}$ & $\begin{array}{r}133 \\
172 \\
81 \\
<40 \\
<\quad 30 \\
393 \\
85 \\
95 \\
79 \\
79 \\
79 \\
63\end{array}$ & $\begin{array}{r}\overline{29} \\
6 \\
\overline{40} \\
15 \\
10 \\
12 \\
9 \\
7 \\
19 \\
-\end{array}$ & $\begin{array}{l}\overline{24} \\
\overline{4} \\
\overline{4} \\
\overline{-} \\
\overline{-} \\
- \\
-\end{array}$ & $\begin{array}{l}\overline{1.54} \\
1.81 \\
0.21 \\
0.26 \\
0.58 \\
\overrightarrow{-} \\
\overrightarrow{0.26} \\
\overrightarrow{0.14}\end{array}$ \\
\hline
\end{tabular}

Recovered means regained consciousness and discharged from Neurological Unit.

Intermit tent drainage means CSF drained by opening ventricular drainage tap for a few minutes every two to three hours.

-Indicates no estimate

+ range of pressure recorded over duration of VFP monitoring.

* patient received chlorpromazine within $24 \mathrm{hr}$ of sampling of CSF. 
Table 2 Concentrations of $H V A$, 5-HIAA, and MHPG $(\mathrm{ng} / \mathrm{ml})$ in serial samples of ventricular CSF from patients who were comatose after a tumour or cerebrovascular accident

\begin{tabular}{|c|c|c|c|c|c|c|c|c|c|c|}
\hline & Case & $\begin{array}{l}\text { Age } \\
(y r)\end{array}$ & Clinical details & $\begin{array}{l}\text { Days after } \\
\text { insertion of } \\
\text { cannula }\end{array}$ & $\begin{array}{l}V F P+ \\
(m m H g)\end{array}$ & $H V A$ & 5-HIAA & $\begin{array}{l}M I \\
\text { Tot }\end{array}$ & $\begin{array}{l}G \\
\text { Free }\end{array}$ & $\begin{array}{l}\text { Protein } \\
(\mathrm{mg} / \mathrm{ml})\end{array}$ \\
\hline \multirow[t]{6}{*}{ Recovered } & 10 & 30 & $\begin{array}{l}\text { Subarachnoid haemorrhage } \\
\text { Postoperative coma }\end{array}$ & 2 & $8-13$ & - & 116 & 8 & 11 & 0.28 \\
\hline & 11 & 46 & $\begin{array}{l}\text { Frontal astrocytoma; possible } \\
\text { obstruction of foramen of Monro }\end{array}$ & 0 & $8-14$ & 250 & 65 & 15 & - & - \\
\hline & & & & $\begin{array}{l}2 \\
3\end{array}$ & & $\begin{array}{l}610 \\
941\end{array}$ & $\begin{array}{r}153 \\
93\end{array}$ & $\begin{array}{r}17 \\
9\end{array}$ & 二 & $\begin{array}{l}0.34 \\
0.34\end{array}$ \\
\hline & 12 & 40 & Post-traumatic subdural hygroma & 2 & $10-15$ & 221 & 58 & 16 & - & - \\
\hline & 13 & 50 & $\begin{array}{l}\text { Cystic meningeal formation. Secondary } \\
\text { hydrocephalus; marked enlargement of }\end{array}$ & 0 & $15-20$ & 483 & 247 & 31 & 13 & - \\
\hline & & & third and fourth ventricles & 1 & & 483 & 289 & 29 & 16 & 2.15 \\
\hline \multirow[t]{2}{*}{ Died } & 14 & 6 & $\begin{array}{l}\text { Posterior fossa tumour, medulloblastoma } \\
\text { partly removed. Comatose until death, } \\
\text { 33d after CSF sample. }\end{array}$ & 1 & 7-9 & $688^{*}$ & 135 & - & - & - \\
\hline & 15 & 16 & $\begin{array}{l}\text { Subarachnoid haemorrhage, comatose } \\
\text { until death, } 3 \text { months after CSF sample }\end{array}$ & 0 & $12-15$ & 133 & 51 & 26 & 11 & 1.80 \\
\hline
\end{tabular}

*patient received metoclopramide within $24 \mathrm{hr}$ of sampling of CSF.

tumour or cerebrovascular disease (Table 2). In patients who recovered consciousness and were discharged from the Neurological Unit, the concentrations of the amine metabolites, with the exception of cases 2 and 11 , stayed at about the same level or fell slightly with increased duration of coma. Case 2, in whom there was a steady increase in HVA concentration, had an upper brainstem lesion and made an excellent recovery. Case 11, who showed a similar increase in HVA, had a frontal astrocytoma and also recovered. In the three patients who died (Table 1) there was a tendency for the concentrations of the acid metabolites to fall and the concentration of the glycol metabolite (MHPG) to rise as coma proceeded. Over the last three days of sampling, CSF was drained intermittently from case 9 by opening the drainage tap for a few minutes every two to three hours in an effort to reduce the very high VFP. This procedure did not appear to alter the metabolite levels.

The mean metabolite concentrations in the last CSF sample from patients who recovered and patients who died, regardless of the cause of the coma, are given in Table 3. Excluded from these values are the HVA levels in cases 7 and 14 who received chlorpromazine and metoclopramide respectively. The interval between the last sample of CSF and death was $9.5 \mathrm{hr}$ (case 4), $29 \mathrm{hr}$ (case 8), $15 \mathrm{hr}$ (case 9), 33 days (case 14), and three months (case 15). There were no significant differences between the concentrations of HVA and 5-HIAA in the patients who recovered and in the patients who died. The concentration of total MHPG was significantly higher $(P<0.02)$ in patients who died.
Table 3 Concentrations of $H V A, 5-H I A A$, and $M H P G$ in ventricular $C S F$, with respect to outcome, in patients who had been comatose for 0.5-6 days

\begin{tabular}{lrlrl}
\hline Patients $(N)$ & \multicolumn{3}{l}{$\begin{array}{l}\text { Mean } \pm S D(n) \\
n g / m l\end{array}$} & \\
\cline { 2 - 5 } & $H V A$ & $5-H I A A$ & $\begin{array}{l}\text { MHPG } \\
\text { Total }\end{array}$ \\
\hline & & & $16 \pm 6(8)$ \\
\hline Recovered (10) & $465 \pm 383(9)$ & $103 \pm 68(9)$ & $16 \pm 01(5)$ \\
Died & $(5)$ & $158 \pm 75^{*}(3)$ & $87 \pm 61(5)$ & $28 \pm 8 \dagger(4)$ \\
\hline
\end{tabular}

*Excluded are two patients with high HVA values who were given chlorpromazine or metoclopramide within $24 \mathrm{hr}$ of sampling the CSF (see text). $\dagger \mathrm{P}<0.02$.

\section{Discussion}

The concentrations of HVA, 5-HIAA, and total MHPG in ventricular CSF were similar to reported values (Gordon and Oliver, 1971; West et al., 1972; Porta et al., 1975; Wilk, 1976). Our observation that about $75 \%$ of MHPG in ventricular CSF is unconjugated is in agreement with the work of Chase et al. (1973). In four patients (cases 3, 4, 13, and 14), the concentration of HVA in the first CSF sample was greater than $400 \mathrm{ng} /$ $\mathrm{ml}$-that is, outside the range of $130-330 \mathrm{ng} / \mathrm{ml}$ found in the other 11 patients. The high HVA in case 14 was probably the result of treatment with metoclopramide which increases the concentration of HVA in mouse brain (Peringer et al., 1978). Cases 4 and 13 were known to have ventricular dilatation, attributable in case 13 to a tumour blocking outflow from the third ventricle. Such a block could be expected to produce a rise in the concentration of HVA in ventricular CSF by pre- 
venting access of the ventricular CSF to the HVA reabsorption site in the region of the fourth ventricle (Guldberg et al., 1966). West et al. (1972) found increased levels of the acid metabolites in samples of ventricular CSF from patients with posterior fossa tumours who had blockade of the CSF outflow pathways. The increased HVA in the second sample from case 7 was probably related to the administration of chlorpromazine $25 \mathrm{mg}$ intramuscularly within $24 \mathrm{hr}$ of removing the sample of CSF (Fyrö et al., 1974). Other drugs given to the patients have not been reported to alter amine metabolite concentrations. The interval of four hours between samples would allow, under normal conditions, for regeneration of the maximum volume of $3 \mathrm{ml}$ withdrawn from the lateral ventricle (Davson, 1967). The effect of the sample volume on the concentrations of the metabolites in ventricular CSF has not been determined.

The similar metabolite concentrations found in the acute and chronic patients do not support the hypothesis that damage to the aminergic cell bodies is a feature of coma associated with acute head injury. Satisfactory comparison of the effects of progression of coma on the metabolite levels in the acute and chronic group cannot be made because serial samples were obtained from only two chronic patients. Interesting trends were, however, seen if the patients were considered with respect to outcome rather than to cause of coma. In five of the seven patients who recovered from whom serial samples were obtained, there was no marked or consistent change in CSF metabolite levels as coma proceeded. In two patients (cases 2 and 11) there was a progressive rise in HVA. The clinical picture of case 2 suggested he had a rostral brainstem injury which could have involved the substantia nigra. Destruction of the dopaminecontaining cells of this region in rats produces a progressive fall in the dopamine content of the terminals in the caudate nucleus between 30 and 48 hours after making the lesion (Ungerstedt, 1971). Since released dopamine is metabolised rapidly to HVA and the levels of HVA in ventricular CSF parallel the levels in the caudate nucleus (Guldberg and Yates, 1969), the progressive rise of HVA concentrations in ventricular CSF from case 2 could reflect trauma-induced release of dopamine from the nigrostriatal system. If this damage did occur, it did not appear to have any clinical significance, since the patient made a good recovery. The foregoing explanation cannot, however, be applied to case 11 who had a frontal astrocytoma and no clinical signs of brainstem injury. In the three patients who died from whom repeat samples of CSF were obtained, there was a tendency for the concentrations of the acid metabolites to decrease and the concentration of total MHPG to rise, as coma progressed. The significantly higher total MHPG found at day 0 or after 1-6 days of coma in the five patients who died was not accompanied by increases in the levels of the acid metabolites, suggesting that the increased MHPG concentration was not related to a reduced formation of CSF. Free MHPG, which accounted for $75 \%$ of the total MHPG in ventricular CSF, is, unlike HVA and 5-HIAA, removed from CSF by rapid diffusion into the brain capillaries (Wolfson and Escriva, 1976). The observed rise in MHPG in ventricular CSF could, therefore, be the result of an antemortem reduction in the cerebral circulation. A steady increase in ventricular MHPG levels in coma might, therefore, serve as an indication of brain death.

We are grateful to Professor G. W. Ashcroft and Professor F. J. Gillingham for suggesting this project, and to Mrs Lorraine Mackenzie for careful technical assistance.

\section{References}

Chase, T. N., Gordon, K., and Ng, L. K. Y. (1973). Norephinephrine metabolism in the central nervouso system of man: studies using 3-methoxy 4hydroxyphenylethylene glycol levels in cerebrospinalo fluid. Journal of Neurochemistry, 21, 581-587.

Dahlström, A., and Fuxe, K. (1964). Evidence for theô existence of monoamine containing neurons in the central nervous system. Acta Physiologica Scandinavica, 62, Suppl. 232.

Davidson, D., Pullar, I. A., Mawdsley, C., Kinloch, N., and Yates, C. M. (1977). Monoamine metabolites in cerebrospinal fluid in multiple sclerosis. Journal of Neurology, Neurosurgery, and Psychiatry, 40, 741-745.

Davson, H. (1967). Physiology of the Cerebrospinal Fluid, pp. 122-132. J. and A. Churchill: London.

Fyrö, B., Wode-Helgodt, B., Borg, S., and Sedvall, G. (1974). The effect of chlorpromazine on homovanillic acid levels in cerebrospinal fluid of schizophrenic patients. Psychopharmacologia (Berlin), 35, 287-294.

Gordon, E. K., and Oliver, J. (1971). 3-Methoxy-4hydroxyphenylethylene glycol in human cerebrospinal fluid. Clinica Chimica Acta, 35, 145-150.

Guldberg, H. C., Ashcroft, G. W., and Crawford, T. B. B. (1966). Concentrations of 5-hydroxyindolylacetic acid and homovanillic acid in the cerebrospinal fluid of the dog before and during treatment with probenecid. Life Sciences, 5, 15711575.

Guldberg, H. C., and Yates, C. M. (1969). Effects of chlorpromazine on the metabolism of catechola- 
mines in dog brain. British Journal of Pharmacology, 36, 535-548.

Jouvet, M. (1972). The role of monoamines and acetylcholine containing neurones in the regulation of the sleep-waking cycle. Reviews of Physiology, 64, 166-307.

Lowry, O. H., Rosebrough, N. J., Farr, A. C., and Randall, R. J. (1951). Protein measurement with the Folin phenol reagent. Journal of Biological Chemistry, 193, 265-278.

Peringer, E., Jenner, P., Donaldson, I., Marsden, C. D., and Miller, E. (1978). Metoclopramide and dopamine receptor blockade. Neuropharmacology, 15, 463-466.

Porta, M., Bareggi, S. R., Collice, M., Assael, B. M., Selenati, A., Calderini, G., Rossanda, M., and Morselli, P. L. (1975). Homovanillic acid and 5hydroxy-indole-acetic acid in the CSF of patients after a severe head injury. II. Ventricular CSF concentrations in acute brain post-traumatic syndromes. European Neurology, 13, 545-554.

Tsementzis, S. A. (1978). Significance of the ven- tricular fluid pressure wave form in the diagnosis of cerebral circulatory arrest and brain death. Acta Neurochirurgica, 40, 191-202.

Ungerstedt, U. (1971). In 6-Hydroxydopamine and Catecholamine Neurons, pp. 113-114. Edited by $\mathrm{T}$. Malmfors and H. Thoenen. North-Holland Publishing Company: Amsterdam.

West, K. A., Edvinsson, L., Nielsen, K. C., and Roos, B-E. (1972). Concentration of acid monoamine metabolites in ventricular CSF of patients with posterior fossa tumours. In Intracranial Pressure: Experimental and Clinical Aspects, pp. 331-337. Edited by M. Brock and H. Dietz. Springer-Verlag: Berlin.

Wilk, S. (1976). Metabolism of biogenic amines in the central nervous system of man. In Proceedings of the Sixth International Congress of Pharmocology, vol. 3, pp. 245-254. Edited by J. Tuomisto and M. K. Paasonen. Pergamon Press: Oxford.

Wolfson, L. I., and Escriva, A. (1976). Clearance of 3-methoxy-4-hydroxyphenylglycol from the cerebrospinal fluid. Neurology (Minneapolis), 26, 781-784. 